\title{
LUMBER GRADES RECOVERED FROM PRUNED DOUGLAS FIR TREES ${ }^{1}$
}

\author{
BY C. F. MCBRIDE
}

C. F. McBride received a B.A.Sc. degree in forest engineering from the University of British Columbia in 1935. He served in various capacities with the British Columbia Forest Service from 1935-45, when he joined the Vancouver Laboratory as a sawmill specialist. He presently heads the Utilization Section.

\section{$A B S T R A C T$}

Butt logs from eleven 49-year-old Douglas fir trees which had been pruned 28 years ago were sawn into lumber. The lumber grades were compared with those recovered from unpruned logs. An average of $18 \mathrm{per}$ cent clear lumber was cut from the pruned logs and negligible amounts from the unpruned butt logs.

\section{INTRODUCTION}

As foresters in British Columbia prepare for a second growth economy in Douglas fir forests on the coast, it is a difficult problem to determine what the end use of these trees will be and whether characteristics of the wood presently considered important will retain their value. However, clear wood volume is a characteristic that will probably continue to be highly valued.

Pruning to obtain improved recovery of clear wood is used in intensive forest practice (1). But to date in British Columbia pruning has been done only on limited areas. The earliest pruning was done in 1930 at the Cowichan Lake Forest Experiment Station of the British Columbia Forest Service.

In 1957 a group of logs from the pruned trees on the Cowichan Lake Experimental Station was processed for veneer, and the results reported by the Vancouver Laboratory of the Forest Products Research Branch showed a remarkable yield of clear veneer (2).

In 1958, in order to assess the volume of clear sawn lumber gained from pruning trees, a small sample of logs cut from pruned trees was studied on a co-operative basis by the British Columbia Forest Service, British Columbia Forest Products Limited, and the Vancouver Laboratory. Only a limited number of logs was available, but analyses of these are at least indicative of potential returns from the pruning of Douglas fir in British Columbia.

\section{The SAMPLe}

The pruning plots at the Cowichan Lake Experiment Station were located in a stand of site index 140 which originated in 1909 following logging and two fires. These plots were established in 1930 when the crop trees were pruned to heights varying from 14 to 24 feet. In 1947 on thinned and pruned

\footnotetext{
${ }^{1}$ A contribution of the Vancouver Laboratory, Forcst Products Research Branch, Department of Forestry of Canada.
} 
plots further pruning was carried out to a total height of 34 feet (4). The trees used in this study were mostly in the dominant and codominant classes.

In 1930 the average d.b.h. of all the pruned trees in B.C. Forest Service plots 195 and 197 (3) was 5.1 inches. By 1956 it had increased to 10.6 inches.

Because thinned and pruned plots are still being maintained on experimental areas at Cowichan Lake, only a limited number of pruned and released trees were available for this study. The largest had been selected for a previous veneer study and the rest were used in the lumber recovery study. Because the pruned only plots were abandoned for remeasurement and the tree number tags removed in 1947, by 1958 only four trees could be identified positively from the original plot maps. Their detailed histories are shown in Table 1 to illustrate the rate of growth of the trees studied. Sample trees were cut into as many 16-foot logs as could be obtained to an 8-inch top, and the logs were divided into three groups:

Group 1-Eleven logs from plots 195 and 197 (3) were from the butt portion of trees pruned but not released by thinning in 1930 .

Group 2-Five logs from plots 204 and 205 (3) were cut from the portions of the trees which were pruned in 1947. In each case a butt log (pruned in 1930) had been cut the year before for the veneer study and the remaining lengths of the logs were held for this study.

Group 3-Nineteen logs were cut from the unpruned portion of the trees from which veneer logs had been cut. They were the second, third, and in a few cases, the fourth 16 -foot logs from these trees. These logs were used to obtain an indication of the quality of unpruned logs from this stand because in all but one tree from which pruned butt logs were cut for the lumber study, the tops were storm-damaged or too small to be used for logs.

TABLE 1

Details of Tree Histories

\begin{tabular}{|c|c|c|c|c|c|c|c|c|}
\hline $\begin{array}{l}\text { Tree } \\
\text { No. }\end{array}$ & $\begin{array}{c}\text { D.B.H. } \\
1958 \\
\text { (in.) }\end{array}$ & $\begin{array}{c}\text { Proned } \\
\text { Height } \\
\text { (ft.) }\end{array}$ & $\begin{array}{c}\text { Total } \\
\text { Heicht } \\
\text { (ft.) }\end{array}$ & $\begin{array}{c}\text { Total } \\
\text { Vol. } \\
\text { (Cu. ft.) }\end{array}$ & $\begin{array}{c}\text { D.B.H. } \\
\text { ig30 } \\
\text { (in.) }\end{array}$ & $\begin{array}{c}\text { Diam. at } \\
\text { top of } \\
\text { pruned } \\
\text { portion } \\
1930 \\
\text { (in.) } \\
\end{array}$ & $\begin{array}{l}\text { Annual } \\
\text { D.B.H. } \\
\text { Growth } \\
\text { (in.) }\end{array}$ & $\begin{array}{c}\% \text { Area } \\
\text { healed } \\
5 \text { years } \\
\text { after } \\
\text { pruning }\end{array}$ \\
\hline 117 & 14.1 & 18.0 & 108 & 47 & 5.9 & 2.7 & 0.29 & $100 \%$ \\
\hline 128 & 14.2 & 16.0 & 105 & 45 & 5.8 & 2.0 & 0.30 & $\begin{array}{l}100 \% \\
\text { except } 2 \\
\text { large knots }\end{array}$ \\
\hline 172 & 10.5 & 26.6 & 100 & 26 & 5.4 & 3.3 & 0.18 & $\begin{array}{l}75 \%- \\
\text { several } \\
\text { pitch knots }\end{array}$ \\
\hline 60 & 9.8 & 20.5 & 94 & 21 & 5.3 & 3.4 & 0.16 & $\begin{array}{l}100 \%-1 \\
\text { pitch knot }\end{array}$ \\
\hline
\end{tabular}




\section{Procedure}

Logs were processed through a whole log barker at a sawmill and were sawn on a pony band mill. Cutting instructions were to saw for maximum recovery of clear lumber 1 and 1\% inches thick by 3 inches and wider, and to cut the construction grades $17 / 8$ inches thick by 4 to 10 inches in width with the last cant on the carriage having a minimum of 4 inches in thickness.

The rough green lumber from each $\log$ was tallied separately and graded according to the British Columbia Lumber Manufacturers' Association Standard Grading and Dressing Rules No. 56. Under these rules only the B and Better Industrial Clears are restricted to a minimum of 6 annual rings per inch in the clear grades.

\section{RESULTS}

Details of lumber grade recovery by diameter classes are shown in Table 2 for the Group 1 logs from trees pruned in 1930 .

As would be expected, the percentage of clear lumber recovered from the logs pruned in 1930 increased rapidly with increase in diameter. Logs in the 8-inch diameter class showed no appreciable amount of clear. In the 9-inch class the clear amounted to 28 per cent for two logs but sweep in one $\log$ reduced its clear lumber recovery to 4 per cent. The one $\log$ in the 11inch class gave a clear volume of 44 per cent.

None of this lumber was degraded for excessive rate of growth.

The lumber from these small logs was necessarily in narrow widths. Of the clear volume, 14 per cent averaged 2 and 3 inches wide, 54 per cent 4 inches wide, and 32 per cent 6 inches wide.

TABLE 2

Group 1-Logs from Trees Pruned in 1930 Average Lumber Tally and Lumber Grade Recovery By Log Diameter Classes

\begin{tabular}{|c|c|c|c|c|c|c|c|c|c|c|}
\hline \multirow[b]{2}{*}{ 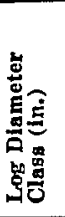 } & \multirow[b]{2}{*}{ 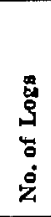 } & \multirow[b]{2}{*}{ 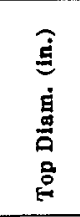 } & \multirow[b]{2}{*}{ 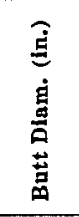 } & \multirow[b]{2}{*}{ 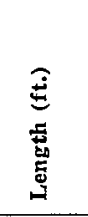 } & \multirow[b]{2}{*}{ 总 } & \multirow[b]{2}{*}{ 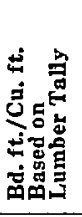 } & \multirow[b]{2}{*}{ 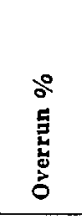 } & \multicolumn{3}{|c|}{$\begin{array}{l}\text { Percentage Lumber } \\
\text { Grade Recovery }\end{array}$} \\
\hline & & & & & & & & $\begin{array}{l}\text { 峞 } \\
\text { d }\end{array}$ & 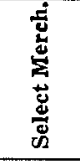 & $\begin{array}{l}+\dot{0} \\
\text { क् } \\
\text { ठ }\end{array}$ \\
\hline 8 & 4 & 8.3 & 10.1 & 16.0 & 42.0 & 6.3 & 31.4 & 2.8 & 75.0 & 22.2 \\
\hline 9 & 3 & 9.2 & 10.6 & 12.7 & 49.6 & 7.7 & 55.1 & 18.6 & 63.6 & 17.8 \\
\hline 10 & 3 & 10.2 & 12.2 & 14.7 & 61.2 & 6.1 & 21.5 & 21.4 & 68.5 & 10.1 \\
\hline 11 & 1 & 10.8 & 12.0 & 16.0 & 80.9 & 7.0 & 17.2 & 43.9 & 56.1 & - \\
\hline Av. & 11 & 9.3 & 11.0 & 14.7 & 52.9 & 6.6 & 33.3 & 18.4 & 61.9 & 19.7 \\
\hline
\end{tabular}

The Group 2 logs pruned in 1947 (Table 3) produced only a small amount of clear lumber. The percentages of selected common and construction lumber were comparable to the yields of Group 3 logs cut from the unpruned portions of trees, indicating that 10 years was too short a time to produce clear lumber. It is interesting to note that on one log the saw-cut 
TABLE 3

Percentage Lumber Grade Recovery by Log Groups 2 and 3

\begin{tabular}{|c|c|c|c|c|c|c|c|c|c|c|c|}
\hline & \multirow[b]{2}{*}{ 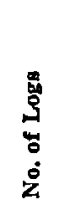 } & \multirow[b]{2}{*}{ 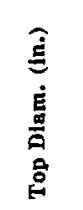 } & \multirow[b]{2}{*}{ 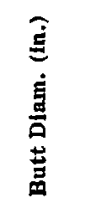 } & \multirow[b]{2}{*}{ 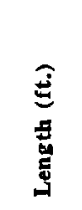 } & \multirow[b]{2}{*}{ 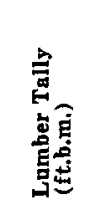 } & \multirow[b]{2}{*}{$\begin{array}{l}0 \\
\vdots \\
5 \\
0 \\
0 \\
0 \\
0\end{array}$} & \multicolumn{5}{|c|}{ Percentage Lumber Grade Recoverg } \\
\hline & & & & & & & $\begin{array}{l}\text { נ̆ } \\
\text { Uू }\end{array}$ &  & $\begin{array}{l}\stackrel{\leftrightarrow}{0} \\
\text { है }\end{array}$ & 峁 & 疍 \\
\hline Group 2 & 5 & 11.9 & 13.3 & 16.0 & 102.6 & 25.1 & 1.3 & 60.8 & 28.8 & 5.5 & 3.6 \\
\hline Group 3 & 19 & 10.7 & 12.0 & 15.7 & 81.1 & 26.6 & 0.6 & 42.4 & 46.1 & 9.5 & 1.4 \\
\hline $\begin{array}{l}80 \text {-yr } \\
\text { unpruned } \\
\text { butt logs- } \\
1951 \text { study }\end{array}$ & 19 & 13.9 & 一 & 23.5 & - & - & 0.6 & & 8.3 & 10.4 & 0.7 \\
\hline
\end{tabular}

exposed areas of pitch where climbing spurs used in the pruning had injured the wood.

The lumber grades sawn from Group 3 logs show lumber grades normal for second growth timber that has not been pruned. In an earlier study lumber grades recovered from the butt logs of unpruned 80-year-old Douglas fir trees shown in Table 3 are almost identical to those obtained from Group 3 logs.

Although no general conclusions can be made because of the limited sample of logs that was available for this study, it is noted that there was a considerable difference in clear lumber volume yield between the butt logs of this 49-year-old stand pruned 28 years ago and the unpruned butt-logs of an 80-year-old stand. Also, the results show that a considerable increase in clear lumber can be obtained by pruning the faster growing trees. The trees which grew at the rate of 0.3 inch d.b.h. per year in the 28 years after pruning produced 32 per cent clear lumber from the butt logs of 10.3 inches top d.i.b., and a tree with an average growth rate of 0.16 inch d.b.h. per year in the 28 years after pruning produced only 6.4 per cent clear from a log 8.3 inches top d.i.b.

\section{REFERENCES}

1. WARRACK, GEORGE. Thinning and pruning of second-growth Douglas fir in the Coastal Region of British Columbia. Research Note No. 13, B.C.F.S. 1948.

2. FENSOM, K. G. Veneer recovery from pruned and unpruned Douglas fir logs. Mimeo No. 1022, Vancouver Laboratory, FPIC. 1957.

3. FINNIS, J. M. Experimental pruning of Douglas fir in British Columbia, Research Note No. 24, B.C.F.S. 1953.

4. SCHENSTROM, S. R. 1931. Pruning experiments in Second Growth Stands of Douglas fir. For. Chron. $7: 220-232$. 